\title{
COMPARISON OF THE OVULATION RATE, FERTILITY AND BIRTH WEIGHT IN SHEEP OF TRAKIAN MERINO BREED AND THEIR CROSSES WITH BOOROOLA
}

\author{
Staika Laleva ${ }^{1}$, Petia Slavova ${ }^{1}$, Nikola Pacinovski ${ }^{2}$, Georgi Bonev ${ }^{3},{\text { Goce } \text { Cilev }^{4} \text {, Yovka Popova }}^{1}$ \\ ${ }^{1}$ Institute of Agricultural Sciences - Stara Zagora, Bulgaria \\ 2 "Ss. Cyril and Methodius" University in Skopje, Institute of Animal Science, \\ Blvd. Ilinden 92a, 1000 Skopje, Republic of Macedonia \\ ${ }^{3}$ Trakia University, Faculty of Agriculture - Stara Zagora 6000, Bulgaria \\ 4 "St. Clement of Ohrid" University of Bitola, Veterinary Faculty, \\ Prilepska bb, 7000 Bitola, Republic of Macedonia \\ pkslavova@abv.bg
}

\begin{abstract}
The aim of this study was to compare the Trakian Merino sheep and their crossbreeds with Booroola in terms of their ovulation rate, fertility and birth weight. The investigations were made with 3 groups of animals: The I one 46 daughters of 4012 ram who is crossbreed with $50 \%$ Booroola, the II one - 132 daughters of 509 ram who is crossbreed with $62.5 \%$ Booroola, and III one - 158 Trakian Merino breed sheep. The highest ovulation rate showed daughters of ram 4012 that amounted $2.875 \pm 0.314$ number (aged 1.5 years), i.e. $2.8353 \pm 0.522$ (aged 2.5 years). In daughters of ram 509, ovulation rate values for these ages were somewhat lower and amounted to $2.560 \pm 0.057$, or $2.400 \pm 0.320$. The lowest ovulation rate had daughters of III group (Trakian Merino), who averaged $1.526 \pm 0.137$ for the age of 1.5 years, i.e $1.575 \pm 0.147$ for those animals who were aged 2.5 years. The highest fertility displayed daughters of ram 4012: $1.375 \pm 0.117,1.500 \pm 0.129$ and $1.500 \pm 0.244$ number for ages of $2.5,3.5$ and 4.5 years, respectively, while the lowest fertility was recorded in daughters of Trakian Merino, the values constituted were 1.175 $\pm 0.063,1.333 \pm 0.065$ and $1.391 \pm 0.102$ number, respectively for the ewes of the similar age. The highest and lowest value for the birth weight for male lambs were identified with those obtained from 509 ram daughters, aged 2.5 and 3.5 years, respectively. In terms of birth weight of female lambs, the highest value was determined in lambs born from Trakian Merino daughters, aged 4.5 years, and the lowest in those obtained from the daughters of ram 509, at the age of 3.5 years
\end{abstract}

Key words: sheep; Trakian Merino breed; Booroola; ovulation rate; fertility; birth weight

\section{СПОРЕДБА НА ПРОЦЕНТОТ НА ОВУЛАЦИЈА, ПЛОДНОСТА И ПОРОДНАТА ТЕЖИНА ПОМЕЃУ ОВЦИТЕ ОД РАСАТА ТРАКИСКИ МЕРИНО И НЕГОВИТЕ МЕЛЕЗИ СО БУРУЛА}

\footnotetext{
Целта на ова истражување беше да се споредат овците од расата тракиски мерино со неговите мелези со бурула во однос на процентот на овулација, плодноста и породната тежина. Истражувањето вклучуваше три групи животни: првата имаше 46 ќерки на овен со број 4012, инаку мелез со 50\% бурула, втората група вклучуваше 132 ќерки од овен со број 509, кој е мелез со 62,5\% бурула, и третата група вклучуваше 158 овци од расата тракиски мерино. Највисок процент на овулација беше утврден кај ќерките од овенот со број 4012, кај кои изнесуваше $2,875 \pm 0,314$ броја (на возраст од 1,5 години), односно $2,833 \pm 0,522$ (на возраст од 2,5 години). Кај ќерките од овен со број 509 вредностите на процентот на овулација за истата возраст беа нешто пониски и изнесуваа околу $2,560 \pm 0,057$, односно $2,400 \pm 0,320$. Најнизок процент на овулација имаа ќерките од третата група (тракиски мерино), кои во просек имаа $1,526 \pm 0,137$ броја за возраст од 1.5 години, односно $1,575 \pm 0,147$ броја кај истите животни, но на возраст од 2,5 години. Највисока плодност имаа ќерките од овенот 4012 , и тоа: $1,375 \pm 0,117,1,500 \pm 0,129$ и $1,500 \pm 0,244$ броја, на возраст од $2.5,3,5$ и 4,5 години, соодветно, додека најниска плодност беше утврдена кај ќерките од овенот тракиски мерино, чии вредности изнесуваа: $1,175 \pm 0,063,1,333 \pm 0,065$ и $1,391 \pm 0,102$ броја, соодветно за овците од слична возраст.
} 
Највисоката и најниската вредност на породната тежина на машките јагниња беа идентификувани кај оние добиени од ќерките на овенот 509 на возраст од 2,5 и 3,5 години соодветно. Во однос на породната тежина кај женските јагниња, највисока вредност беше утврдена кај јагнињата добиени од ќерките на тракиски мерино на возраст од 4,5 години, а најниска кај оние добиени од ќерките на овен 509 на возраст од 3,5 години.

Клучни зборови: овци; раса тракиски мерино; бурула; процент на овулација; плодност; породна тежина

\section{INTRODUCTION}

Meat is a main product from the sheep breeding, having a relatively stable price and market in Bulgaria. With this respect the number of the lambs born and weaned has always been an important factor. Crossing with high fertility breeds like Booroola Merino and Finnsheep is often used to increase the total productivity, especially the number of the lambs born.

There are two types prolific ewes - fertility is either controlled by numerous genes (Romanov, Finnsheep) or by one gene with a large effect on the ovulation rate like in the Booroola and Cambridge breeds. The ovulation rate in heterozigotic ewes by this gene is increased with $0.5-1.5$ times and in homozigotic ones with 3.3. The Booroola crossbreed have $5 \%$ lower live weight, produced $6 \%$ less wool, but have about $20 \%$ more weaned lambs per ewe and this is a characteristic feature of this gene.

Booroola Merino $\left(\mathrm{B}^{\circ} \mathrm{M}\right)$ ewes have a high ovulation rate and litter size which in 1980 was postulated to be due to the effects of a major gene $\left(\mathrm{Fec}^{\mathrm{B}}\right)$. This was confirmed in breeding experiments and $\mathrm{Fec}^{\mathrm{B}}$ was subsequently shown to be due to a mutation $(B M P R-1 B)$ on chromosome 6 . The mutation has recently been found in native sheep breeds in India, China and Indonesia and it is likely that $\mathrm{Fec}^{\mathrm{B}}$ in the Australian $\left(\mathrm{B}^{\mathrm{O}} \mathrm{M}\right)$ was derived from importations of Garole sheep from India in 1792 and 1793 (Fogarty, 2009). The similar data also reported Davis (2005), who pointed out that the recent study investigating the gene's origin led to its discovery in dwarf Garole sheep in northeast India. The Garole (also known as Bengal), which are very similar to the Booroola Merino is a direct descendant of these sheep. The prolific Javanese sheep of Indonesia, previously known as $\mathrm{Fec}^{\mathrm{J}}$, also carry the Booroola gene.

The high ovulation rate and prolificacy of Booroola Merino sheep is due to a limited number of strictly linked genes or by a single autosomal gene. Since prolificacy is one of the important parameters which affect the efficiency of the sheep industry, the effects of the presence of one or two copies of the $\mathrm{Fec}^{\mathrm{B}}$ gene have been studied not only on reproductive physiology and genetics, but also on production traits and management in numerous countries (Abella et al., 2005).

Ewes inheriting one copy of the Booroola gene from either parent produced about 1.5 extra eggs and gave birth to about 1.0 extra lamb per ewe lambing. Homozygous carriers produced about 3.0 extra eggs resulting in about 1.5 extra lambs per ewe lambed. Uptake of the Booroola gene has been limited due to past difficulties in identifying carrier sheep and the extra management required to profitably benefit from the very large increase in litter size. However, sheep carrying the Booroola gene derived from the Australian Booroola Merino are bred in at least 13 countries, in addition to native breeds carrying the BMPR1B mutation in India and Indonesia (Davis, 2005).

This gene influences granulosa cell maturation, oocyte development and its function. The increase in prolificacy is due to autosomal mutation that occurred in this gene which causes increase in ovulation rate and litter size. Term "Booroola" originates from the name of the ranch in Australia, where the sheep carrying single gene for prolificacy were first discovered. Booroola gene can be transferred to any other breed by crossbreeding. This $\mathrm{Fec}^{\mathrm{B}}$ gene is responsible for the higher prolificacy of Finn sheep, Romanov, Booroola Merino and British Milk Sheep (Abraham and Thomas, 2012). The main objective of the present research was_to compare the Trakian Merino sheep and their crossbreed with Booroola in terms of their ovulation rate, fertility and birth weight.

\section{MATERIAL AND METHODS}

The investigations were made with 3 group of animals: The I one - 46 daughters of 4012 ram who is crossbreed with $50 \%$ Booroola, the II one 132 daughters of 509 ram who is crossbreed with 62.5\% Booroola, and 158 Trakian Merino breed sheep all treated by laparoscopie what about the third group. The only possibility to establish if this rams are heterozigotics by F-gene was by testing its offsprings. The ewes were synchronized in the breeding season by applying vaginal tampons Chrono-gest (Intervet; Holland, $40 \mathrm{mg}$ Cronolone 
"gree" staying 12 days. The same tampons, but "white", placed for 14 days were used in primaparous sheep. The gonadotropic medecin Folligon - $400 \mathrm{IU}$ was applied immediatelly after withdrawal of the tampons. The ewes were inseminated 54-55 $\mathrm{h}$ after removing the tampons while the primaparous ones were inseminated $48-50 \mathrm{~h}$ after sponge removal. The ovulation rate was recorded three days after the laparoscopic insemination. All lambs born from the daughters of the rams 509 and 4012 were weighed. A combined (barn-pasture) system of husbandry was used, which comprises vegetation during 7-8 months, while in the rest of the year, the sheep were fed with meadow hay $(1 \mathrm{~kg} /$ day, November-February) and concentrate mixture $(0.5 \mathrm{~kg} / \mathrm{day}$,)November-April). The influence of the effects of what were studied by F-test, (SPSS, 1994).

\section{RESULTS AND DISCUSSION}

The ovulation rate at the age of 1.5 and 2.5 years in crosses was is significantly higher in comparison with the purebred sheep (Table 1). The ovulation rate in the daughters of the ram 4012 are higher than in daughters of the ram 509, despite of the higher Booroola blood participation in its genotype.

Specifically, the highest ovulation rate showed the daughters of ram 4012, that amounted 2.875 \pm 0.314 number (aged 1.5 years), i.e $2.833 \pm 0.522$ number (aged 2.5 years). In the daughters of ram 509 , ovulation rate for these ages were somewhat lower and constituted $2.560 \pm 0.057$ or $2.400 \pm$ 0.320 number.

The lowest ovulation rate had the ewes of III group (Trakian Merino), who averaged $1.526 \pm$ 0.137 eggs, for the age of 1.5 years, i.e $1.575 \pm$ 0.147 eggs for those animals which were aged 2.5 years.

The differences in ovulation rate are statistically proved at $p<0.05$. Both groups have by one animal with ovulation rate value -5 eggs at the first lambing, and 3-4 eggs at the second lambing. According to Davis and Hinch (1998), as F-gene bearers are considered the animals having ovulation rate over 3 eggs. The results suggested the existing of the F-gene in the rams utilized for crossing the flock of the Institute of Cattle and Sheep Husbandry. Young and Dickerson (1991) reported a signifficant superiority concerning the ovulation rate in the crossbreeds with Booroola Merino in comparison with Finnsheep.
On the Table 2 can be seen the daughters fertility of the rams 509, 4012 and the purebreed ewes at different ages.

Similar to the data in Table 1, the highest fertility have daughters of ram 4012: $1.375 \pm 0.117$ lamb, $1.500 \pm 0.129$ and $1.500 \pm 0.244$ lambs for subsequent ages of $2.5,3.5$ and 4.5 years, while the lowest fertility had daughters Trakian Merino, showing values of $1.175 \pm 0.063,1.333 \pm 0.065$ and $1.391 \pm 0.102$ lambs for the same age, respectively.

It has been analyzed all daughters of the rams, including those with registrated ovulation rate unclear sentence. The ewes from the first group had the highest fertility at all ages. The second group showed increasing in the numbers of the lambs born at the age of 3.5 years -1.444 , after that this indicator decreased to 1.250 . The difference between groups_are not significant. Similar result reported Gootwine et al. (1992) and Klewiec et al. (1996). Despite of the high ovulation rate the fertility is inadequate. This is probably due to the nutrition inadequacies or is the consequence of embryo mortality.

The birth weights data are shown on Table 3 . The highest and lowest birth weights were identified in male lambs born of 509 ram daughters, aged 2.5 and 3.5 years, respectively. In terms of birth weight of female lambs, the highest value was determined in lambs derived from Trakian Merino daughters aged 4.5 years, and the lowest in those obtained from the daughters of ram 509, at the age of 3.5 years (Tab. 3).

The birth weight fluctuations were in the limits representative of the Trakian Merino breed. The ram male lambs have highest birth weight from the female once in all groups. No significant difference were established between the crossbreed and the purebreeds ewes at all ages.

Considering the birth weight and growth rate in Booroola $\times$ Merinos d'Arles, Abella et al. (2005) concluded that live weight and average daily gain did not depend on the genotype effects. Similar data report Fogarty et al. (1995) in crossbreed Poll Dorset with Booroola.

Kumar et al. (2008) determined that the $\mathrm{Fec}^{\mathrm{B}}$ genotypes were significantly $(P<0.01)$ associated with the lamb's body weights from birth to 12 months of age. The generation wise $\left(F_{1}, F_{2}\right.$ and $\left.F_{3}\right)$, lamb's body weight did not differ significantly at birth, 6 and 12 months of the age, while it differed significantly $(P<0.05)$ at 3 and 9 months of age. 
Table 1

Ovulation rate of the daughters of the rams 4012 and 509, crossbreeds with Booroola and pure breed

\begin{tabular}{lccc|rcc}
\hline \multirow{2}{*}{ Breeds } & \multicolumn{3}{c|}{1.5 years of ages } & \multicolumn{3}{|c}{2.5 years of ages } \\
& $n$ & $\mathrm{x} \pm \mathrm{Sx}$ & $\mathrm{C} \%$ & $n$ & $\mathrm{x} \pm \mathrm{Sx}$ & $\mathrm{C} \%$ \\
\hline Ram 4012 - I group & 10 & $2.875 \pm 0.314^{*}$ & 28.86 & 6 & $2.833 \pm 0.522 *$ & 42.46 \\
Ram 509 - II group & 19 & $2.560 \pm 0.057^{*}$ & 37.50 & 10 & $2.400 \pm 0.320^{*}$ & 42.40 \\
Tracian Merino - III group & 26 & $1.526 \pm 0.137$ & 32.71 & 21 & $1.575 \pm 0.147$ & 36.95 \\
\hline \hline
\end{tabular}

Significance: $P<0.05$

Table 2

Fertility of the daughters of the rams 4012 and 509, crossbreeds with Booroola and pure breed

\begin{tabular}{lccc|ccc|ccc}
\hline \hline \multirow{2}{*}{ Breeds } & \multicolumn{3}{c|}{2.5 years of ages } & \multicolumn{3}{c|}{3.5 years of ages } & \multicolumn{3}{c}{4.5 years of ages } \\
& $n$ & $\mathrm{x} \pm S x$ & $C \%$ & $n$ & $x \pm S x$ & $C \%$ & $n$ & $x \pm S x$ & $C \%$ \\
\hline Ram 4012 - I group & 24 & $1.375 \pm 0.117$ & 41.81 & 16 & $1.500 \pm 0.129$ & 34.40 & 6 & $1.500 \pm 0.244$ & 36.46 \\
Ram 509 - II group & 55 & $1.236 \pm 0.057$ & 34.78 & 45 & $1.444 \pm 0.075$ & 34.76 & 32 & $1.250 \pm 0.095$ & 43.04 \\
Tracian Merino - III group & 63 & $1.175 \pm 0.063$ & 41.95 & 54 & $1.333 \pm 0.065$ & 35.71 & 41 & $1.391 \pm 0.102$ & 46.51 \\
\hline \hline
\end{tabular}

Table 3

Birth weight of the lambs born from the daughters of the rams 4012 and 509 crossbreeds with Booroola and pure breed

\begin{tabular}{|c|c|c|c|c|c|c|c|c|c|}
\hline \multirow{3}{*}{ Breeds } & \multicolumn{9}{|c|}{ Birth weight } \\
\hline & \multicolumn{3}{|c|}{2.5 years of ages } & \multicolumn{3}{|c|}{3.5 years of ages } & \multicolumn{3}{|c|}{4.5 years of ages } \\
\hline & $n$ & $\mathrm{x} \pm \mathrm{Sx}$ & $\mathrm{C} \%$ & $n$ & $\mathrm{x} \pm \mathrm{Sx}$ & $\mathrm{C} \%$ & $n$ & $\mathrm{x} \pm \mathrm{Sx}$ & $\mathrm{C} \%$ \\
\hline Ram 4012 ram lambs male lambs & 21 & $4.509 \pm 0.184$ & 18.23 & 12 & $4.750 \pm 0.291$ & 20.32 & & & \\
\hline Ram 4012 ewe lambs female lambs & 10 & $4.220 \pm 0.194$ & 13.81 & 12 & $4.292 \pm 0.235$ & 18.22 & & & \\
\hline Ram 509 ram lambs male lambs & 35 & $4.885 \pm 0.189$ & 22.55 & 35 & $4.031 \pm 0.150$ & 21.75 & 20 & $4.175 \pm 0.197$ & 20.64 \\
\hline Ram 509 ewe lambs female lambs & 33 & $4.212 \pm 0.108$ & 14.52 & 30 & $3.836 \pm 0.166$ & 23.38 & 21 & $3.885 \pm 0.225$ & 25.94 \\
\hline TM ram lambs male lambs & 48 & $4.520 \pm 0.154$ & 23.43 & 27 & $4.552 \pm 0.117$ & 13.12 & 27 & $4.537 \pm 0.192$ & 22.02 \\
\hline TM ewe lambs female lambs & 35 & $4.001 \pm 0.204$ & 29.72 & 45 & $4.577 \pm 0.131$ & 18.99 & 30 & $4.633 \pm 0.158$ & 18.35 \\
\hline
\end{tabular}

\section{CONCLUSIONS}

The daughters of the rams 4012 and 509 displayed by 1.0 to 1.3 higher ovulation rate at the age of 1.5 and 2.5 years. These crossbreed animals have better production rate in comparison with the purebreed ones.

The results confirm the positive effect of Booroola gene in other breeds entering the crossing, in terms of improvement of the ovulation and fertility, as one of the basic preconditions for im- proving productivity, and thus profitability of the sheep breeding.

In regard to the indicator "birth weight" it was not found significant differences between crossbreeds and purebreds.

\section{REFERENCES}

[1] Abella F. D., Cognie Y., Thimonier J., Seck M., Blanc R. M.: Effects of the $\mathrm{Fec}^{\mathrm{B}}$ gene on birth weight, postnatal growth rate and puberty in Booroola $\times$ Mérinos d'Arles 
ewe lambs. Anim. Res. 54 283-288. INRA, EDP Sciences (2005).

[2] Abraham, A., Thomas, N.: Role of Fecundity genes in prolificacy of small ruminants. J. Ind. Vet. Assoc. Vol. 10, Issue 3, pp 34-37 (2012).

[3] Davis, G., Hinch, G.: Genetics of reproduction in sheep, Elsevier Ltd, 1998, pp. 156-169.

[4] Davis H. G.: Major genes affecting ovulation rate in sheep. 2005. Genet. Sel. Evol. 37 (Suppl. 1) (2005) S11S23. INRA, EDP Sciences (2004).

[5] Fogarty, M. N., Hall, D., Gilmour, A.: Performance of crossbreed progeny of Trangie fertility Merino and Booroola Merino rams and Poll Dorset ewes. Austr.J. Eper. Agric., 35, pp 1075-1082 (1995).

[6] Fogarty, M. N.: A review of the effects of the Booroola gene (FecB) on sheep production. Small Ruminant Research, Vol. 85, Issues 2-3, pp 75-84 (2009).

[7] Gootwine, E., Braw-Tal, R., Bor, A., Goot, H., Shalhevet, D., Zenou, A.: Lamb and milk production in Awassi, As- saf, Booroola-Awassi and Booroola-Assaf sheep in Israel. Proc. of New Zeal. Soc. of Anim. Prod, 52, pp 203206 (1992)

[8] Klewiec, J., Gabryazuk, M., Bakanowski, A., Janiuk, W.: Current problems in Polish sheep breeding. Ani;. Sci. Papers and Rep, 14, pp 5-11 (1996).

[9] Kumar, S., Mishra, K. A., Kolte, P. A., Arora, L. A., Singh, D., Singh, K. V.: Effects of the Booroola (FecB) genotypes on growth performance, ewe's productivity efficiency and litter size in Garole x Malpura sheep. Animal Reproduction Science, Vol. 105, Issues 3-4, pp 319-331 (2008).

[10] SPSS.: SPSS 6.1 for Windows Student Version. Chicago, USA (1994).

[11] Young, L. D., Dickerson, E. G.: Comparison of Booroola Merino and Finnsheep: effects on productivity of mates and performance of crossbreed lambs, J. Anim. Sci., 69, 5, pp 1899-1911 (1991). 